\title{
IMPACT OF THE LIFE CYCLE OF COMPANY TO JOB SATISFACTION
}

\author{
Snežana Kirin, Milan Mitrović, Siniša Borović, Aleksandar Sedmak
}

Original scientific paper

There is increased evidence indicating that employees who experience high levels of job satisfaction are also more productive. The job satisfaction is affected by Internal and external factors. The aim of this study was to investigate the relationship of internal factors of job satisfaction, such as satisfaction with the content of work, conditions of work, relationships with colleagues and managers with life stage of company through study of job satisfaction in companies that are in various stages of their life cycle.

Keywords: job satisfaction; life cycle of company

Istraživanje zadovoljstva poslom ovisno o životnom stadiju tvrtke

Izvorni znastveni rad

Postoji sve veći broj dokaza koji ukazuju da su zaposlenici koji doživljavaju visoku razinu zadovoljstva poslom i produktivniji. Na zadovoljstvo poslom utječu i unutarnji i vanjski čimbenici. Cilj ovog istraživanja bio je ispitati odnos unutarnjih čimbenika zadovoljstva poslom, kao što su zadovoljstvo sa sadržajem rada, plaćom, uvjetima rada, odnosima s kolegama i menadžerima u zavisnosti od životnog stadija tvrtke kroz istraživanje provedeno u tvrtkama koje se nalaze u različitim fazama svog životnog ciklusa.

Ključne riječi: zadovoljstvo poslom; životni stadij tvrtke

\section{Introduction}

In response to the setting of Taylor's theories of scientific management from the first half of the last century, a significant number of theorists have studied the human factor in economic development. The beginning of this effort is linked to the famous Hawthorne study and its results called the Hawthorne effect about employee's productivity. These studies were a major effort to explore, in a systematic way, the impact of environmental factors on the productivity of the workforce, as described in [1]. The key researcher, Elton Mayo, concluded that employees have responded to the increased attention by making extra effort no matter what the experimental conditions. Also, Mayo suggested that this effect was generalizable to many other contexts.

After that Maslow has developed the well-known hierarchy of needs, positioning the concept of selfactualisation at the top level, as described in [2]. Argyris emphasized the importance of the individual maintaining his individuality and self-determination within the large organisation. McGregor suggested in his theory that man is a self-actualising creature. Herzberg analysed satisfaction and dissatisfaction of person's work in the scope of two-factor theory and pointed out that they were determined by different factors. Work as a vehicle for self-actualisation certainly seems to be important in the life of some individuals. Although work is not the unique source of personal satisfaction in life, there is considerable evidence to show that the job is one of the central sources of this need for satisfaction, [2].

There are various definitions of general satisfaction with the job. However, all of them are mostly confined to the affective relationship to work, taking into account the favourable and unfavourable aspects of the job. Job satisfaction is usually defined as pleasant feeling which arises from the perception that one's job fulfils or allows the fulfilment of the important aspects of the value system of a person. The level of job satisfaction is not easy to measure because the definition of satisfaction is not the same for all people.

Motivation and satisfaction of employees has become the basis of stability of modern companies. Dissatisfied workers may not provide the growth and development of the company and the presence of dissatisfaction is an important indicator of future problems. Understanding the issues of job satisfaction is essential for the design of the workplace, implementing organizational culture, creating motivation system and reward system and defining management style.

Taking into account theories of employee motivation, job satisfaction can be associated with many organizational and personal factors, Fig. 1. In addition to these factors, the job satisfaction is influenced by environmental factors and the overall economic and political situation. The financial crisis five years ago had little negative impact on overall job satisfaction in many countries. In countries in transition, such as Serbia, workers are in a position to be lucky if they are employed, as the unemployment rate is extremely high.

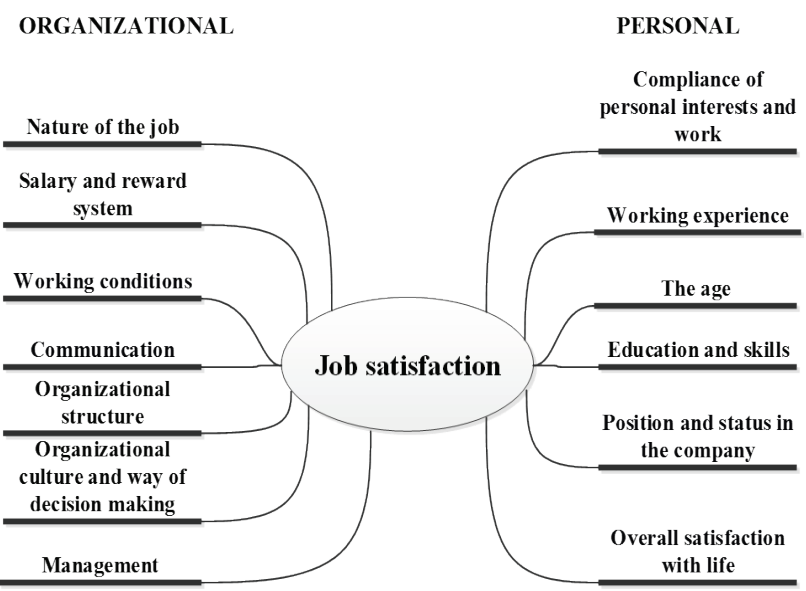

Figure 1 Factors affecting job satisfaction 
The phenomenon of the life cycle has long been known, not only in biology, but also in many other scientific disciplines. There are several theories of the life cycle of companies, which only partially coincide. Phases of the life cycle of companies come and go one by one by predetermined order, but different theorists have different views on the number of life cycle stages of companies. According to Right Start Consulting, [3], life cycle includes start-ups or early-stage companies, high-growth ventures, mature companies, and companies facing turnaround situations. Usually life cycle is presented with two axes diagram, where $\mathrm{x}$ axis represents time and $\mathrm{y}$ axis represents revenues, profits or cash flows. Some authors consider life cycle of organization to consist of six stages: Conception, Birth \& Formalization, Development, Consolidation \& Maturity, Decline and Dissolution, [4]. In the research presented here the following classification is used:

- Phase foundation and development ("go-go")

- $\quad$ Phase early age (adolescence)

- $\quad$ Phase full maturity (top form)

- Early stage of bureaucracy

- Phase bureaucracy

- Late phase of bureaucracy ("death" of the company).

The foundation and development phase is the period when the company was born and the company is in a growth phase. During the phase of early youth, companies recognize that there is life outside their founders, as Isak Adizes stated [5]: „In many ways companies act similarly to a teenager, trying to become independent of the family." It is the beginning of movement of the company to success. The transition between the "go-go" stage and adolescence is difficult, because there is a need for delegation of authority, change of leadership and setting of new goals. Top form represents optimal state in the life cycle of company when it achieves a balance between the ability to keep processes under control and flexibility. Early stage of the bureaucracy is the beginning of falling performances. The aim of this paper is to explore the dimensions of job satisfaction with social aspects depending on the life stage of company.

\section{Research methodology}

The survey was conducted in eight companies that are diverse in their activities, ownership rights, qualifications, education and age structure.

To determine in which phase of the life cycle companies are, assumptions about the characteristics of each stage, as given in the theory, were taken into account, as well as the length of the existence of companies, development of their economic activities and interviews with employees.

The survey was conducted during working hours, at workplace of respondents, using a questionnaire in which a Likert type ranking scale is used. The sample contained 125 respondents. Complexity of the impact of factors that affect job satisfaction and their activities was highlighted through a questionnaire.

Information on the respondents and their personal characteristics is meant to provide data that are consi- dered most relevant to the research problem, and relate to the following six variables:

- Gender,

- Level of Education,

- The age,

- Years of service,

- Activities of the company,

- Type of employment.

The main hypothesis was:

H0: Job satisfaction depends on the phase of the life cycle of the company.

Data were processed by the appropriate mathematical and statistical procedures. The plan of research is based on the correlation between the variables of the general level of education, work experience, education, gender, employment type (independent) and job satisfaction, relationships, relationships with colleagues and superiors, satisfaction with work conditions (dependent variable).

For the analysis of job satisfaction with job content, satisfaction with rewarding system of work, relationships with colleagues, managers and overall relationships depending on the phase of the life cycle of company, ANOVA analysis (one factor) of different groups, were applied, with additional tests.

In order to find the mutual relationship between job satisfaction and life cycle stages of the company Pearson's correlation was used. Statistical data analysis was performed using the algorithms embedded in software applications, Microsoft's "Excel" and "Statistical Package for the Social Sciences (SPSS)" for Windows".

\subsection{Place and conditions of research}

The conditions in which firms operate at the time of research can be named unstable because it is a period of economic crisis during the last phase of a long transitional period of privatization and restructuring. Deindustrialization and decline of activities of the Serbian industry and economy is the process that takes nearly a quarter century and is characterized by: narrowing of industrial production; devastation of industrial capacities; reduced productivity in the industrial sector; out-of-date industrial equipment and technologies; decline in the competitiveness of major industries and companies, especially those with export ambitions; decreased share of industrial sector in GDP of Serbia; decline in export activities; reduction of the number of employees in the industrial sector.

According to the Survey on labour employment in April 2010, using adjusted methodology of International Labour Organization, the unemployment rate was 20,1\% and the employment rate $47,2 \%$, which was unfavourable compared to the EU, [6].

\subsection{Independent variables}

In this paper company sizes are classified into four categories: up to 50 employees, 51 to 100 employees, 101 to 1000 employees, over 1000 employees, being somewhat different from EU Commission recommendation concerning the definition of micro, small and medium-sized enterprises, [7]. Such a classification was made due to practical reasons, since the observed 
companies were very different both in the ownership structure and their size.

The sample was used to investigate whether the hypothesis was influenced by the gender of (male and female).

Four categories of the age of respondents were analysed: up to 30 years, 31 to 40 years, 41 to 50 years, and over 50 years.

Level of education is given in five categories: primary school, three-year secondary school, four-year high school, college degree, university degree.

Working experience is determined by the four categories: 5 years, 6 to 10 years, 11 to 20 years, over 20 years.

Type of employment is given in four categories: fulltime, part-time, freelance, and volunteers.

The ownership structure of the company is presented in three categories: stock company, limited liability, and state ownership.

Tab. 1 represents the age structure and working experience, Tab. 2 represents the level of education, and Tab. 3 shows the phase of the life cycle of company.

Table 1 The age structure and working experience

\begin{tabular}{|l|l|l|l|}
\hline \multicolumn{2}{|c|}{ The age structure } & \multicolumn{2}{c|}{ Working experience } \\
\hline Less than 30 years & $13 \%$ & Less than 5 years & $19 \%$ \\
\hline $31 \div 40$ years & $21 \%$ & $6 \div 10$ years & $10 \%$ \\
\hline $41 \div 50$ years & $24 \%$ & $11 \div 20$ years & $12 \%$ \\
\hline More than 50 years & $42 \%$ & More than 20 years & $59 \%$ \\
\hline
\end{tabular}

Table 2 Level of education

\begin{tabular}{|l|c|}
\hline Primary school & $12 \%$ \\
\hline Three year secondary school & $17 \%$ \\
\hline A four year high school & $38 \%$ \\
\hline College & $11 \%$ \\
\hline University degree & $22 \%$ \\
\hline
\end{tabular}

Table 3 The phases of the life cycle

\begin{tabular}{|l|c|}
\hline Phase foundation and development & $6 \%$ \\
\hline Phase early age (adolescence) & $17 \%$ \\
\hline Phase full maturity (top form) & $38 \%$ \\
\hline Early stage of bureaucracy & $6 \%$ \\
\hline Phase bureaucracy & $26 \%$ \\
\hline Late phase of bureaucracy & $7 \%$ \\
\hline
\end{tabular}

The number of respondents is the same regarding male and female gender $(50 \%) ; 32 \%$ of respondents are working in manufacturing sector, and $68 \%$ are in service sector.

\subsection{Dependent variables}

With the aim to highlight the influence of phase of the life cycle of company, the following was analysed: satisfaction with the content of job, satisfaction with working conditions (workplace equipment, hours of operation), satisfaction with rewarding the work, satisfaction with relationships with colleagues and managers and satisfaction with working atmosphere in relation to phase of the life cycle of the company.

For the purpose of this research a questionnaire with 5 variables is constructed. For each question five responses were offered representing views of respondents, categorized by using a Likert-type rating scale format with five ordered response options:

1 - "strongly disagree"
2 - "disagree"

3 - "no opinion"

4 - "agree"

5 - "strongly agree.

\section{Results}

To answer the question: "Do the results of measuring satisfaction of: job content, award system, relationships with colleagues, relationships with managers and human relations, differ in general, depend on the phase of company life cycle?" the statistical analysis, one-factor ANOVA (ANalysis Of VAriance), is performed.

One of the assumptions of ANOVA analysis is that the variances of groups being compared are similar. In order to check it, the Levene's test of homogeneity of variance is applied, reduced to testing of the null hypothesis:

HV0: variances are equal (there is no strong evidence that the differences in the variances of the different phases of the life cycle of the company are significant).

HV1: the variance differences are significant.

Tab. 4 shows results of Levin's test of homogeneity of variance, examining the equality of variances in the results in each of the six groups of the life cycle of company. Columns represent Levene F statistic (Levene statistic), the degrees of freedom (dfl and df2) for pairs of independent and dependent variables and statistical significance (sig. p-value). When the "Sig." is greater than 0,05 , it means that the null hypothesis is true, i.e. that the variances are equal. In other words, in this case the assumption of homogeneity of variance is not violated. In our case, Sig. $>0,05$ is satisfied for variables that examine the content of job satisfaction, rewards, human relations in general and relations with colleagues, while it is not satisfied for the variables examining satisfaction with relationships with managers and pleasure of working conditions, because Sig. $<0,05$. In these cases, because the variance is not the same for all six groups of independent variables "phase of the life cycle", the null hypothesis is rejected and instead of ANOVA statistics, the test of robustness is applied, using the median instead of the mean value.

Table 4 Levene's test of homogeneity of variance

\begin{tabular}{|l|c|c|c|c|}
\hline & $\begin{array}{c}\text { Levene } \\
\text { statistic }\end{array}$ & $d f 1$ & $d f 2$ & Sig. \\
\hline Job content & 1,934 & 5 & 119 & 0,094 \\
\hline Job conditions & 3,187 & 5 & 119 & 0,01 \\
\hline Rewards & 1,217 & 5 & 119 & 0,305 \\
\hline Relationship with colleagues & 1,888 & 5 & 119 & 0,101 \\
\hline Management & 2,411 & 5 & 119 & 0,040 \\
\hline Interpersonal relationship & 1,601 & 5 & 119 & 0,165 \\
\hline
\end{tabular}

The results of ANOVA analysis are shown in Tab. 5. Based on these results the following can be concluded:

- Significant differences in the mean values of the dependent variable "satisfaction with job conditions" between the phases of adolescence and bureaucracy.

- Significant difference in satisfaction with job conditions between the phases "top form "and the bureaucracy. 
For the dependent variable "satisfaction with rewarding system," one obtains:

- Significant difference between satisfaction with the rewarding system in the "phase foundation and development" and during the phase "top form";

- Significant differences between satisfaction with rewarding system in phase "top form" and the last stage of the life cycle of the company.

Fig. 2 shows the average value of the degree of satisfaction of respondents for each phase of the life cycle of company. Fig. 2 indicates that employees are mostly content with relationship with their colleagues at work, being fairly balanced throughout all phases of the life cycle of company. which can be interpreted as belonging to a nation characterized by the collectivist dimension of culture, [8].

Satisfaction with management is highest in the initial, foundation and development stage, when there is the greatest enthusiasm, and then drops significantly during adolescence to increase under top form and stage of bureaucracy, when working procedures are developed and ways of working established.

Satisfaction with interpersonal relationships is highest in the beginning, when the expectations are highest, to the lowest value reached under top form when it is expected that the company operates at full capacity and when it is expected that all other parameters follow that development.

Respondents expressed mostly balanced satisfaction with the content of work which shows that employees are generally realistically assessed with what they will work on. Slightly higher values of satisfaction of the content of the work are reported in the foundation and development stage phase and the phase of the bureaucracy.

Satisfaction with the conditions in the workplace is the highest in a bureaucracy stages.

\begin{tabular}{|c|c|c|c|c|c|c|}
\hline & & $\begin{array}{l}\text { Sum of } \\
\text { squares }\end{array}$ & $d f$ & $\begin{array}{l}\text { Mean } \\
\text { square }\end{array}$ & $F$ & Sig. \\
\hline \multirow{3}{*}{ Job content } & $\begin{array}{l}\text { Between } \\
\text { groups }\end{array}$ & 9,372 & 5 & 1,874 & 1,625 & 0,158 \\
\hline & $\begin{array}{l}\text { Within } \\
\text { groups }\end{array}$ & 137,236 & 119 & 1,153 & & \\
\hline & Total & 146,608 & 124 & & & \\
\hline \multirow{3}{*}{$\begin{array}{c}\text { Job } \\
\text { conditions }\end{array}$} & $\begin{array}{l}\text { Between } \\
\text { groups }\end{array}$ & 22,76 & 5 & 4,552 & 3,672 & 0,004 \\
\hline & $\begin{array}{l}\text { Within } \\
\text { groups }\end{array}$ & 147,528 & 119 & 1,24 & & \\
\hline & Total & 170,288 & 124 & & & \\
\hline \multirow{3}{*}{ Rewards } & $\begin{array}{l}\text { Between } \\
\text { groups }\end{array}$ & 35,819 & 5 & 7,164 & 4,397 & 0,001 \\
\hline & $\begin{array}{l}\text { Within } \\
\text { groups }\end{array}$ & 193,893 & 119 & 1,629 & & \\
\hline & Total & 229,712 & 124 & & & \\
\hline \multirow{3}{*}{$\begin{array}{c}\text { Relationship } \\
\text { with } \\
\text { colleagues }\end{array}$} & $\begin{array}{l}\text { Between } \\
\text { groups }\end{array}$ & 4,141 & 5 & 0,828 & 0,965 & 0,442 \\
\hline & $\begin{array}{l}\text { Within } \\
\text { groups }\end{array}$ & 102,131 & 119 & 0,858 & & \\
\hline & Total & 106,272 & 124 & & & \\
\hline \multirow{3}{*}{ Management } & $\begin{array}{l}\text { Between } \\
\text { Groups }\end{array}$ & 15,941 & 5 & 3,188 & 2,751 & 0,022 \\
\hline & $\begin{array}{l}\text { Within } \\
\text { groups }\end{array}$ & 137,931 & 119 & 1,159 & & \\
\hline & Total & 153,872 & 124 & & & \\
\hline \multirow{3}{*}{$\begin{array}{l}\text { Interpersonal } \\
\text { relationships }\end{array}$} & $\begin{array}{l}\text { Between } \\
\text { groups }\end{array}$ & 9,318 & 5 & 1,864 & 1,415 & 0,224 \\
\hline & $\begin{array}{l}\text { Within } \\
\text { groups }\end{array}$ & 156,682 & 119 & 1,317 & & \\
\hline & Total & 166 & 124 & & & \\
\hline
\end{tabular}

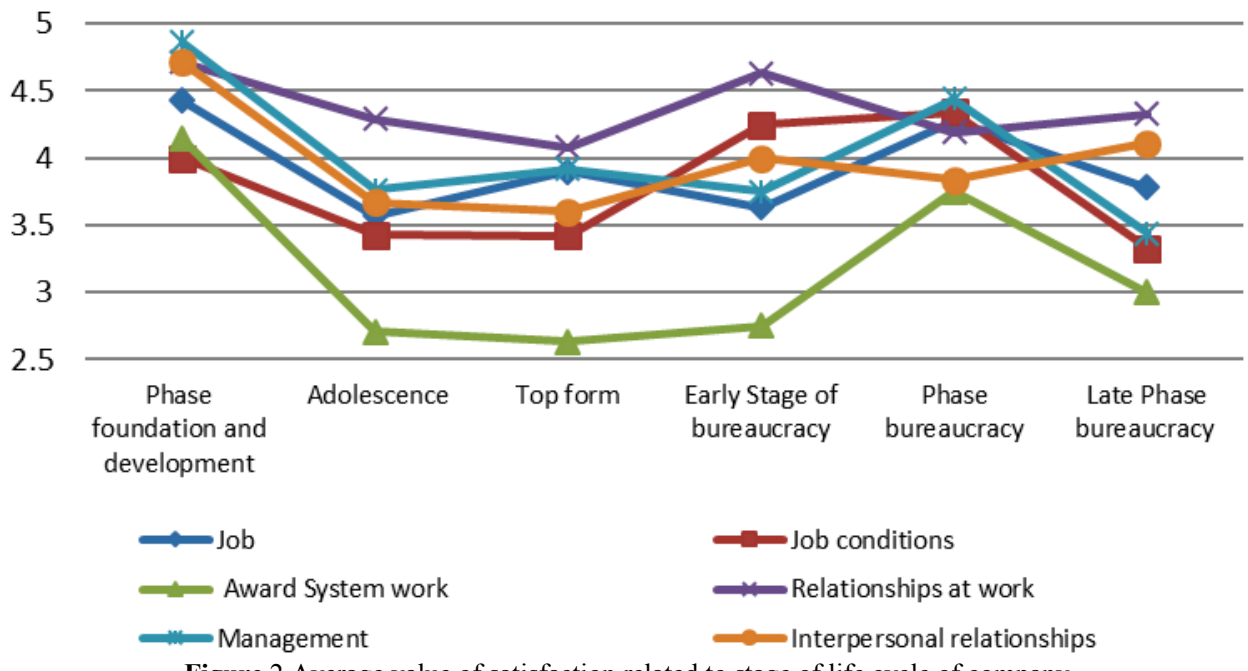

Figure 2 Average value of satisfaction related to stage of life cycle of company

Table 6 Mutual correlations of dependent variables

\begin{tabular}{|c|c|c|c|c|c|c|c|c|c|}
\hline Correlations & & $\begin{array}{l}\text { Economic } \\
\text { branch }\end{array}$ & $\begin{array}{c}\text { Job } \\
\text { content }\end{array}$ & $\begin{array}{c}\text { Work } \\
\text { conditions }\end{array}$ & Rewards & $\begin{array}{l}\text { Relation with } \\
\text { co workers }\end{array}$ & $\begin{array}{c}\text { Relation with } \\
\text { managers }\end{array}$ & $\begin{array}{c}\text { Relationships } \\
\text { generally }\end{array}$ & $\begin{array}{l}\text { Frequency of } \\
\text { conflicts }\end{array}$ \\
\hline Job Content & Pearson & 0,035 & 1 &, $507(* *)$ &, $503(* *)$ &, $285(* *)$ & ,388(**) & $3,369(* *)$ & $\begin{array}{l}-, 244(* *) \\
\end{array}$ \\
\hline Work conditions & Pearson & ,216(*) &, $507(* *)$ & 1 &, $635(* *)$ &, $466(* *)$ &, $606(* *)$ &, $377(* *)$ &,$- 417(* *)$ \\
\hline Rewards & Pearson & ,246(**) & ,503(**) & ,635(**) & 1 &, $510(* *)$ &, $605(* *)$ &, $554(* *)$ &,$- 475(* *)$ \\
\hline $\begin{array}{l}\text { Relation with co- } \\
\text { workers }\end{array}$ & Pearson & 0,127 & ,285(**) & , 466(**) &, $510(* *)$ & 1 & ,697(**) &, $661(* *)$ &,$- 522(* *)$ \\
\hline Relation with managers & Pearson & 0,082 & ,388(**) & ,606(**) &, $605(* *)$ & ,697(**) & 1 &, $649(* *)$ &,$- 540(* *)$ \\
\hline \multirow{2}{*}{ Relationships generally } & Pearson & 0,134 &, $369(* *)$ &, $377(* *)$ &, $554(* *)$ & ,661(**) &, $649(* *)$ & 1 &,$- 588(* *)$ \\
\hline & $\mathrm{N} * * *$ & 125 & 125 & 125 & 125 & 125 & 125 & 125 & 125 \\
\hline
\end{tabular}

* Correlation is significant at the 0,05 level (2-tailed). ** Correlation is significant at the 0,01 level (2-tailed). *** $N$ is number of respondents. 
Satisfaction with the rewarding system resembles the letter $U$ being the highest in the initial stage. After that disappointment is indicated because wages do not follow growth and development of company. In stages when the company is in the most advanced position workers expressed dissatisfaction with the system of rewarding.

By applying the Pearson correlation between the independent and dependent variables the relationship between the factors of job satisfaction and life stage of company is not obtained. The weak correlation between satisfaction of conditions of work and activities of the company is obtained, as well as the weak correlation of satisfaction with reward system and activities of the company.

Mutual correlations between dependent variables are shown in Tab. 6.

By observing the mutual correlation of dependent variables, Tab. 6, the strong correlation of satisfaction with job content and satisfaction with working conditions and satisfaction with reward system is obtained, whereas correlations of satisfaction with job content with satisfaction with relation with co-workers and managers and relationship generally, is of medium intensity.

The strong correlation is obtained for satisfaction with work condition and satisfaction with reward system, satisfaction with relation with co-workers and managers and relationship generally.

Satisfaction with the reward system is strongly correlated to satisfaction with relation with co-workers and managers and relationship generally.

Satisfaction with relation with co-workers is strongly correlated to satisfaction with relation with managers and relationship generally and satisfaction with relation with managers is strongly correlated to satisfaction with relationship generally.

The strong correlation of satisfaction with relationships with managers and satisfaction with relationships with co-workers is also obtained.

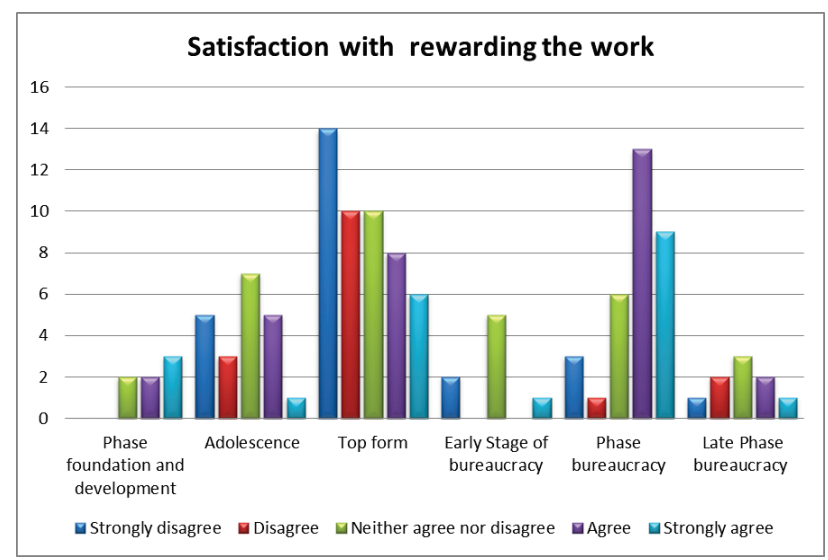

Figure 3 Satisfaction with rewarding the work

Direction of the correlation variable "frequency of conflicts" is reversed with variables "satisfaction with job content" and "working conditions", "satisfaction with reward system", "satisfaction with relation with coworkers" and "satisfaction with relation with managers" and "satisfaction with relationship generally". This is natural, because improved relations and greater job satisfaction result in less frustration, and consequently a smaller number of conflicts, which is precisely the goal of the "strategy of satisfied employees."

In Figs. $3 \div 7$ the cluster diagrams of dependent variables are shown, depending on the stage of the life cycle of company. In this way the detailed structure of the layout of satisfaction and dissatisfaction of certain dependent variables can be seen.

In Fig. 3, cluster diagram of satisfaction with reward system is presented, depending on the stage of the life cycle of company. On the $y$-axis the number of respondents is given, but it should be noted that this number is different for each phase, Tab. 3.

In Fig. 4, cluster diagram of satisfaction with interpersonal relationship is presented, depending on the stage of the life cycle of company. It can be seen that high discontent occurs only during phases "adolescence" and "bureaucracy". Neutral opinion and satisfaction with interpersonal relationship are prevailing at all stages.

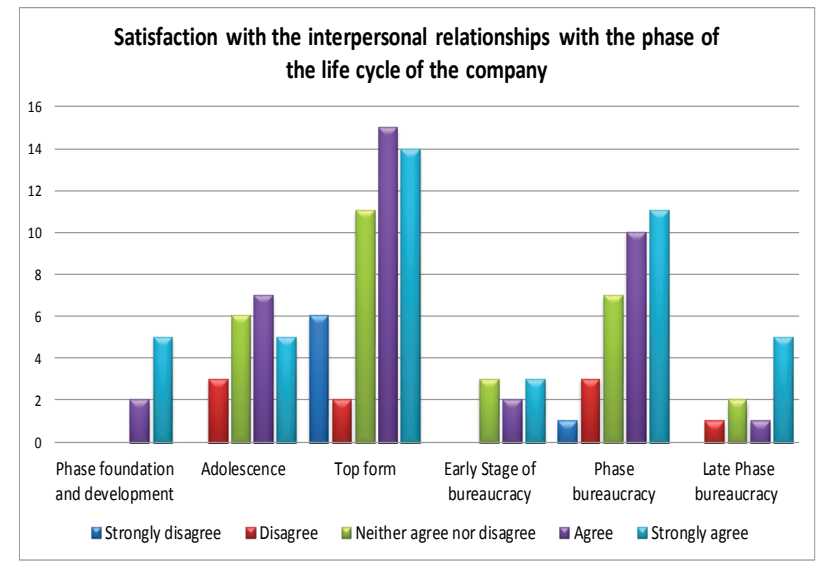

Figure 4 Satisfaction with interpersonal relationship

Regarding the satisfaction with job conditions, Fig. 5, high discontent occurs only during phases "adolescence" and "top form" when maximum effort is expected. Discontent with working conditions is expressed in phases "adolescence", "top form", bureaucracy and the latest phase of life cycle of company. Neutral opinion and satisfaction with working conditions are prevailing at all stages, and satisfaction is the biggest at the bureaucracy stage.

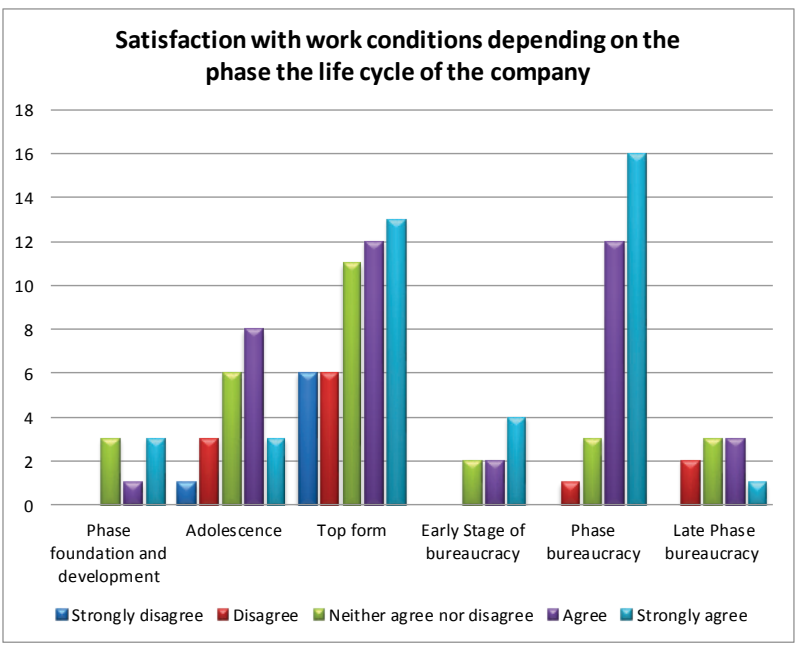

Figure 5 Satisfaction with work conditions 
Fig. 6 shows a cluster diagram containing satisfaction with job content in relation to the stage of the life cycle of company. It can be seen that the maximum expressed satisfaction with the content of the job is in the stage of top form, and somewhat lower in the phase of bureaucracy. It can be seen that a small number of respondents expressed dissatisfaction with the content of work in stages "top form", "bureaucracy" and the last phases of life cycle of company.

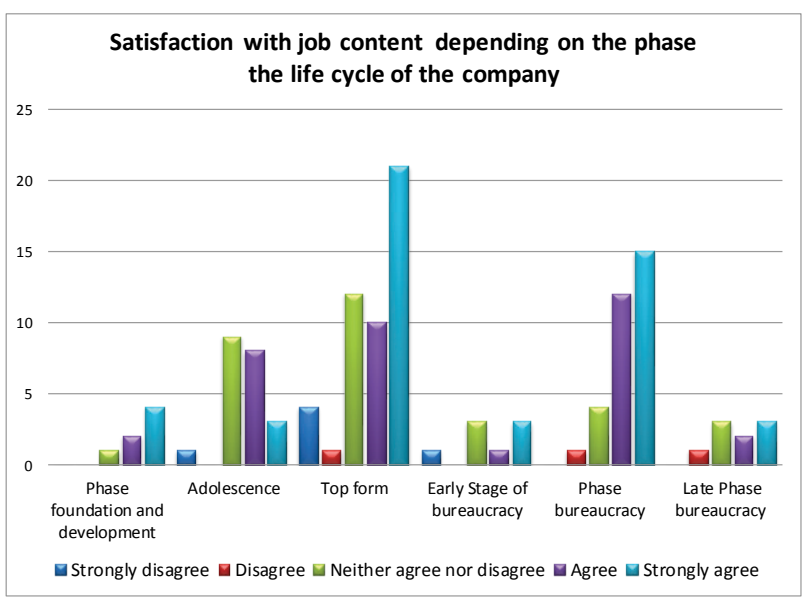

Figure 6 Satisfaction with job content

It can be seen that in the phase "foundation and development", there are no negative attitudes about the reward system, while in the next phase, "adolescence", when the company has already been on the upswing, dissatisfaction is more expressed. Most of the respondents in this stage have no final opinion on reward system.

In the phase of bureaucracy, when the system of work and reward is already established with procedures, the greatest satisfaction with the reward system is expressed, and in the late phase of bureaucracy level of satisfaction almost follows a normal distribution.

In Fig. 7, cluster diagram of satisfaction with relationship with managers is presented, depending on the stage of the life cycle of company. It can be seen that high discontent occurs only during phase "top form". Neutral opinion and satisfaction with relationship with managers are prevailing at all stages.

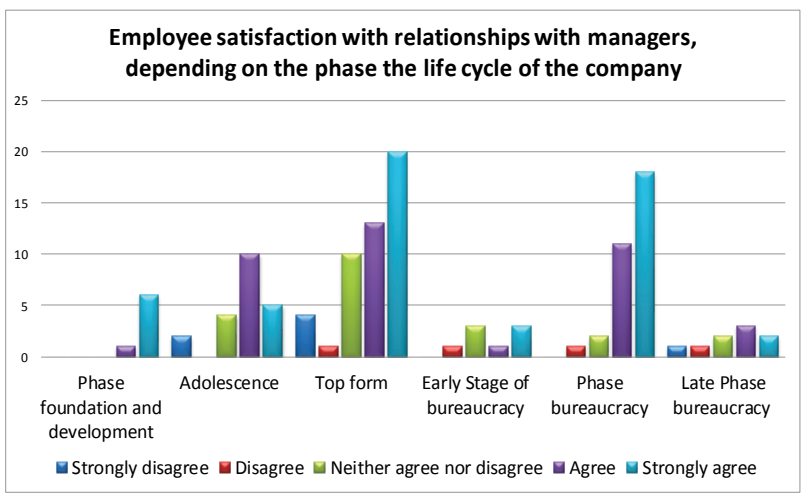

Figure 7 Satisfaction with relationship with managers

As regards conflicts, Fig. 8, they are less pronounced in the foundation and adolescence phase than in the phase of top form and bureaucracy phases. In top form stage the amount of occasional conflicts is by far the largest, although somewhat fewer respondents identified the rare occurrence of conflicts and the least of them existence of frequent conflicts that affect the business of the company.

From all the above it can be concluded that hypothesis $\mathrm{H} 0$, "Job satisfaction depends on the phase of the life cycle of the company", has been proved.

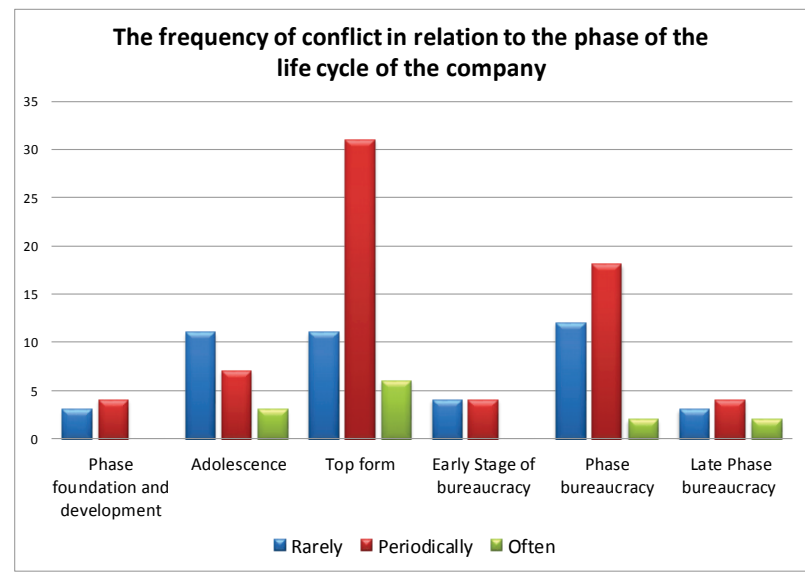

Figure 8 The frequency of conflicts

\section{Discussion}

It is shown that in the first, "foundation and development" phase of the life cycle of company satisfaction with work content is present, as well as with relationships with co-workers and managers, working conditions and rewarding system and overall interpersonal relationships.

At the stage of adolescence, there has been decline of enthusiasm, and consequently decline of satisfaction. The most prominent is neutral attitude towards job content, and occasionally appearing dissatisfaction and satisfaction with job content, Fig. 6. In this stage neutral attitude towards conditions of work is expressed. Regarding rewarding system, almost the same number of respondents who are satisfied and dissatisfied with salaries is recorded. In this phase good relationship with co-workers is predominant. Also satisfaction with general relationships in the company predominates, although there are a few cases of discontent. At this stage, conflicts occur rarely.

At the "top form" stage of life cycle of company, it is expected that the company is operating at full capacities. In this stage satisfaction with work content is the most pronounced. In this phase a full range of satisfaction / dissatisfaction with working conditions is recorded, but the pleasure is more common. Because the company is operating at full capacity, it is normal that employees expected that other working parameters should follow the development of company. Since this is usually not the case, dissatisfaction with rewarding system at this stage is the most pronounced, Fig. 7. At this stage high level of satisfaction with relationship with colleagues, managers and overall relationships between people is evident, though full dissatisfaction with those relationships is sometimes presented. At this stage the largest amount of occasional conflicts is presented, which can be explained with the intensity of the job. A smaller number of the respondents expressed the rare occurrence of conflicts and 
the lowest number of respondents expressed the existence of frequent conflicts that affect the business of company.

After a phase of top form, in the early stage of the bureaucracy, decrease in satisfaction with job content is noticed, what can be explained by disappointment with job opportunities. Also much smaller number of the respondents expressed satisfaction with working conditions. Regarding satisfaction with rewarding system, neutral opinion is presented most often which is different from the opinion in the top form phase, but still dissatisfaction is more presented. In relationships with colleagues, interpersonal relationships and relationships with the managers, there is no dissatisfaction.

At the stage of the bureaucracy satisfaction has grown with the content of work, compared to the early phase of the bureaucracy, after a period of adjustment. At this stage satisfaction with rewarding system is evident, as well as with relationships with colleagues and managers, and human relations. There are a small number of respondents who are dissatisfied with working condition. It should be noted that all procedures for the job are defined and elaborated in written at this stage. The most of occasional conflicts occur at this stage, while a relatively small number of respondents pointed to the rare occurrence of conflicts and the least of them existence of frequent conflicts that affect the business of the company.

When differences in mean values of individual dependent variables at different stages of the life cycle of company are observed, one obtains a significant difference between the mean value of the variable "satisfaction with working conditions" between the phases adolescence and the phase of "the bureaucracy" and the phase "top form" and the "bureaucracy". For the dependent variable "satisfaction with rewarding work," there are significant differences between satisfaction with rewarding system in the phase "top form" and the phase which is the last stage of life cycle of the company.

In the late stage of the bureaucracy satisfaction with job content and neutral attitude towards the content of work is mostly presented. A few respondents expressed dissatisfaction with job content. Regarding conditions of work very few respondents have expressed complete satisfaction. Generally speaking, satisfaction with conditions of work resembles normal distribution. When considering rewarding system, there are all levels of satisfaction/dissatisfaction. Their intensity is small, and the shape reminds of normal distribution. In relationships with colleagues no dissatisfaction occurs, while satisfaction with relationship with managers and interpersonal relationships is more expressed than dissatisfaction.

\section{Conclusions}

Due to the complexity of the human factor in the company, it takes a lot of expertise and relevant skills to successfully guide people's behaviour in accordance with the strategy and goals of the company. This especially applies to finding mechanisms that increase employee satisfaction; improve corporate communication and selection of mechanism of motivation. Although many studies have shown that in this way employee satisfaction and job performance is increased, there is no strict correlation between the transformation of work and increase of operational effectiveness.

The study presented through survey in this paper suggests that the life cycle of company, the atmosphere in which it operates and the energy which is expressed in that process, also represent parameters in an attempt to measure employee satisfaction at work.

It should be kept in mind that the survey was conducted in Serbia, at a time when the unemployment rate is extremely high and there is a large brain drain of highly skilled labour in developed countries and where the fact of "being employed" is the satisfaction by itself, so the results are significant.

\section{Notice}

Short version of this paper has been presented and published in Proceedings of $5^{\text {th }}$ International Scientific and Expert Conference TEAM 2013 [9].

\section{Acknowledgment}

Financial support by Serbian Ministry for Education, Science and Technology is gratefully acknowledged (Project 33044).

\section{References}

[1] Macefield, R. Usability Studies and the Hawthorne Effect. // Journal of Usability Studies. 2, 3(2007), pp. 145-154.

[2] Smith, D. F. The Functions of Work. // OMEGA, The Int. J. of Management Sci. 3, 4(1975). DOI: 10.1016/03050483(75)90002-X

[3] www.rightstartconsulting.com/services/-technologysolutions/

[4] Wegner, D.; Alievi, R. M.; Begnis, H. S. The life cycle of small-firm networks: an evaluation of Brazilian business networks. // Braz. Adm. Rev. 12, 1(2015). DOI: 10.1590/1807-7692bar2015140030

[5] Adizes, I. Managing Corporate Life Cycles, $2^{\text {nd }}$ Edition, Published by the Adizes Institute. 2004.

[6] Revizija nacionalne službe za zapošljavanje Srbije, 2010 http://rs.one.un.org/organizations/12/Revizija\%20Nacional ne\%20sluzbe\%20zaposljavanja\%20Srbije.pdf

[7] Official Journal of the European Union, Commission recommendation, http://eur-lex.europa.eu/LexUriServ/ LexUriServ.do?uri=OJ:L:2003:124:0036:0041:en:PDF

[8] Hofstede, G. International Differences in Work Related Values, Beverly Hills, CA: Sage Publications

[9] Kirin, S. et al. The study of job satisfaction with the phase of life cycle of company. // $5^{\text {th }}$ International Conference TEAM 2013, Prešov, 2013, p. 355.

\section{Author's addresses}

Snežana Kirin, Ph.D.

Innovation center of the Faculty of Mechanical Engineering, Kraljice Marije 16, 11000 Belgrade, Serbia

E-mail: snezanakirin@yahoo.com

Milan Mitrović, Ph.D., Siniša Borović, Ph.D.

University Privredna Akademija, Faculty for Applied Management and Economy, Nemanjina 4, 11000 Belgrade, Serbia

Aleksandar Sedmak, Ph.D.

Faculty of Mechanical Engineering, University of Belgrade, Kraljice Marije 16, 11000 Belgrade, Serbia 